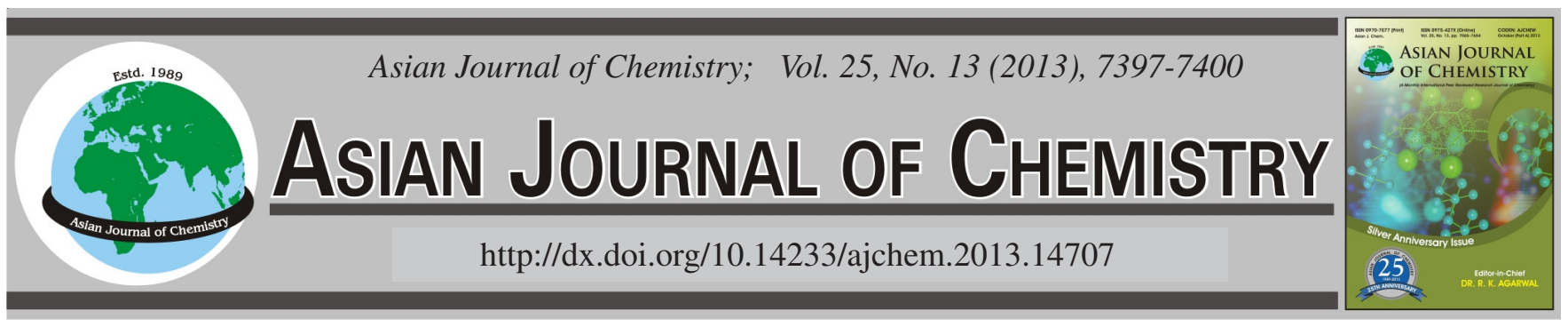

\title{
DNA Binding and Oxidative Cleavage Studies of Supramolecular Copper(II) Complex Based on $\beta$-Cyclodextrin
}

\author{
Si-Ping TAng ${ }^{*}$, Yong-Lan Feng, Zhi-Feng Xu and De-Ping Wang
}

Key Laboratory of Functional Organometallic Materials, Department of Chemistry and Material Science, Hengyang Normal University, Hengyang 421008, Hunan Province, P.R. China

*Corresponding author: Fax: +86 734 3456099; Tel: +86 734 8450056, E-mail: tsp00@163.com

A copper(II) complex $(\mathrm{CuL}, \mathbf{1})$ with aminothioether ligand and its new inclusion complex with $\beta$-cyclodextrin $(\mathrm{CuL} / \beta-\mathrm{CD}, 2)$ have been prepared successfully. The binding modes of both complexes with calf thymus DNA were investigated by UV-visible and circular dichroism spectroscopies. Results show that both complexes mainly adopt electrostatic attraction binding mode with DNA and binding constants are $(2.02 \pm 0.02) \times 10^{3}$ and $(1.79 \pm 0.05) \times 10^{3} \mathrm{M}^{-1}$, respectively. Both complexes are able to cleave pBR322 plasmid DNA efficiently in the presence of ascorbic acid and the activity of $\mathbf{2}$ is higher than that of $\mathbf{1}$. The DNA cleavages by $\mathbf{1}$ and $\mathbf{2}$ were inhibited strongly in the presence of DMSO and tert-butyl alcohol, which suggests that hydroxyl radicals are reactive oxygen species for the cleavage.

Key Words: Copper(II) complex, Inclusion complex, DNA binding, Nuclease activity.

\section{INTRODUCTION}

Cyclodextrins (CDs) are cyclic oligomers, containing an apolar cavity with primary hydroxyl groups lying on the outside and the secondary hydroxyl groups inside ${ }^{1-5}$. Cyclodextrins are widely used as food additives, for stabilization of flavours, for elimination of undesired tastes or other undesired compounds such as cholesterol and to avoid microbiological contaminations and browning reactions ${ }^{6-8}$. In the pharmaceutical industry, cyclodextrins and their derivatives have been used in drugs either for complexation or as auxiliary additives such as solubilizers, diluents, or tablet ingredients to improve the physical and chemical properties or to enhance the bioavailability of poorly soluble drugs ${ }^{9,10}$. Cyclodextrins are used to catalysis reactions to improve the conversion and selectivity ${ }^{11-15}$ in water. The inclusion complexes of cyclodextrins and other small molecules have been used in drug formulations for improving the drug properties such as solubility, stability and bioavailability ${ }^{16-19}$.

In the present work, we successfully synthesized a copper complexes $\mathrm{CuL}(\mathbf{1})$ and its new inclusion complex (2) based on $\beta$-cyclodextrin. We further investigated DNA binding ability and 'chemical nuclease' activity in the presence of ascorbic acid of the two complexes.

\section{EXPERIMENTAL}

Distamycin and SOD were purchased from Sigma-Aldrich Chemical Co., pBR 322 DNA was purchased from MBI, tris(hydroxymethyl)aminomethane (Tris) and catalase were purchased from BBI, CT-DNA and ethidium bromide were purchased from Sino-American Biotechnology, 2,2,6,6tetramethyl-4-piperidone monohydrate (TEMP) was purchased from Acros organic. Other reagents of analytical grades were obtained from domestic chemical corporations and used without further purification except that thionyl chloride was purified by distillation. Milli-Q water was used in all physical measurement experiments.

Microanalyses (C, H and $\mathrm{N}$ ) were carried out on an Elementar Vario EL elemental analyzer. ESI-Mass spectra were recorded using a LCMS-2010A liquid chromatograph mass spectrometer. ${ }^{1} \mathrm{H}$ NMR spectra were collected on a Varian Mercury-plus 300 NMR spectrometer.

Synthesis of complexes 1, 2: The copper complex $(\mathrm{CuL}$, 1) was prepared from 2-(4-tert-butylbenzyl)-1,3-bis(aminoethylthio)propane (L) and $\mathrm{Cu}\left(\mathrm{ClO}_{4}\right)_{2} \cdot 6 \mathrm{H}_{2} \mathrm{O}^{20}$. Anal. calcd. (\%) for $\mathrm{C}_{18} \mathrm{H}_{36} \mathrm{Cl}_{2} \mathrm{CuN}_{2} \mathrm{O}_{10} \mathrm{~S}_{2}$ : C, 33.83; H, 5.68; N 4.38. Found (\%): C, 34.18; H, 5.60; N, 4.49.

Preparation of inclusion complex $(\mathrm{CuL} / \beta$-cyclodextrin, 2): $0.032 \mathrm{~g} 1(0.05 \mathrm{mmol})$ was added to $4 \mathrm{~mL} \beta$-cyclodextrin $(0.601 \mathrm{~g}, 0.05 \mathrm{mmol})$ aqueous solution with stirring for $1 \mathrm{~h}$ at room tempreture. The solution was filtrated and concentrated to remove almost all of the solvent. Blue power was obtained. The powder was recrystallized from $\mathrm{H}_{2} \mathrm{O} / \mathrm{C}_{2} \mathrm{H}_{5} \mathrm{OH}$, filtrated and dried in vacuum desiccator, $0.036 \mathrm{~g}$ blue microcrystal was obtained in $38.1 \%$ yield. Anal. calcd. (\%) for 
$\mathrm{C}_{60} \mathrm{H}_{106} \mathrm{~N}_{2} \mathrm{~S}_{2} \mathrm{O}_{45} \mathrm{CuCl}_{2} \cdot 6 \mathrm{H}_{2} \mathrm{O}: \mathrm{C}, 38.29 ; \mathrm{H}, 6.32 ; \mathrm{N}, 1.49$. Found (\%): C,38.06; H, 6.02; N, 1.46. 2 is characterized by UVvisible spectroscopy further.

Circular dichroism spectroscopy: Circular dichroism spectra of CT-DNA were recorded on a Jasco J-810 spectropolarimeter at room temperature in the absence or the presence of 20 and $40 \mu \mathrm{M}$ complexes $\mathbf{1}$ or $\mathbf{2}(\mathrm{r}=0.2,0.4 . \mathrm{r}=$ [complex]/ [DNA]). The concentration of DNA was $100 \mu \mathrm{M}$ and $5 \mathrm{mM}$ Tris-50 mM NaCl solution ( $\mathrm{pH} 7.5$ ) was the buffer solution. Each test solution was scanned at a speed of $50 \mathrm{~nm} \mathrm{~min}^{-1}$ for four repetitions and the average spectra were used. The buffer background was subtracted automatically.

UV-visible spectroscopy: UV-visible spectroscopy was recorded on a Varian Cary $300 \mathrm{UV}$-visible spectrophotometer attached to a Cary Peltier temperature controller. The concentration of complexes was $60 \mu \mathrm{M}$ and the buffer solution was the same as that of circular dichroism spectroscopy.

DNA cleavage: The cleavage of pBR322 plasmid DNA (38 $\mu \mathrm{M}$ bp) was performed in $20 \mathrm{mM}$ Tris buffer ( $\mathrm{pH}$ 7.2) by treating DNA with a certain concentration of complex in the presence of 20 -fold ascorbic acid. The total volume of $10 \mu \mathrm{L}$ sample solution was incubated in a sealed plastic vessel and the cleavage was carried out at $37^{\circ} \mathrm{C}$ for $1 \mathrm{~h}$, then $4 \mu \mathrm{L}$ loading buffer $(0.05 \%$ bromophenol blue, $50 \%$ glycerol and $2 \mathrm{mM}$ EDTA) was added. The sample was stored at $-20^{\circ} \mathrm{C}$ for preservation, then was loaded onto a $0.9 \%$ agarose gel and electrophoresed at a constant voltage of $120 \mathrm{~V}$ for $100 \mathrm{~min}$ in TBE buffer (100 mM Tris-2 mM EDTA-HBO 3 , pH 8.3). DNA bands were visualized in an electrophoresis documentation and analysis system 120 .

\section{RESULTS AND DISCUSSION}

Preparation of inclusion complex (2): The inclusion complex $\mathbf{2}$ is stable in air and soluble in water. The results of UV-visible spectra is showed in Fig. 1. Compared to $\beta$ cyclodextrin, the absorption position and relative absorption intensity of complex $\mathbf{2}$ have obvious changes. The relative absorption intensity of complex $\mathbf{2}$ is higher than that of $\mathbf{1}$ (1, $323 \mathrm{~nm}\left(\varepsilon, 4809.25 \mathrm{M}^{-1} \mathrm{~cm}^{-1}\right), 244 \mathrm{~nm}\left(\varepsilon, 2645.65 \mathrm{M}^{-1} \mathrm{~cm}^{-1}\right)$; $\left.2,322 \mathrm{~nm}\left(\varepsilon, 5362.45 \mathrm{M}^{-1} \mathrm{~cm}^{-1}\right), 246 \mathrm{~nm}\left(\varepsilon, 2947.45 \mathrm{M}^{-1} \mathrm{~cm}^{-1}\right)\right)$. The maximum absorption position of complex 2 shows blue shift compared to complex $\mathbf{1}$. All those indicate complex $\mathbf{2}$ is just the inclusion complex of $\mathbf{1}$ with $\beta$-cyclodextrin.

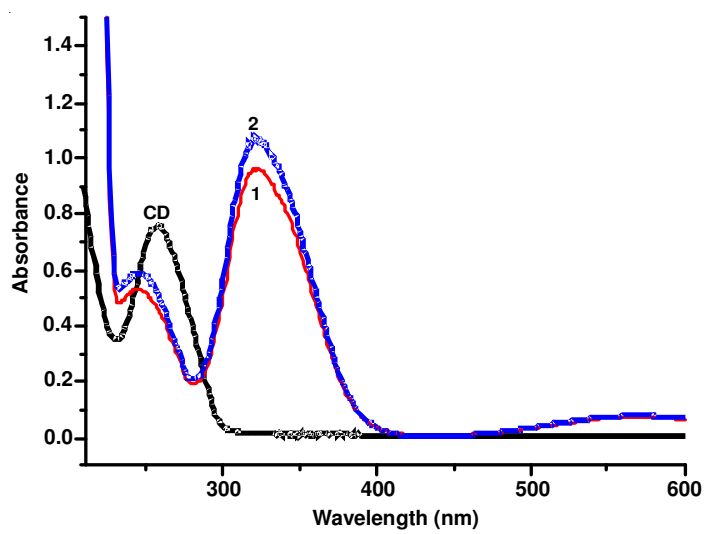

Fig. 1. Electronic spectra of $200 \mu \mathrm{M}$ of $\beta$-cyclodextrin (black line), 1 (red line) and inclusion complex 2 (blue line) in aqueous solution
Interaction with CT-DNA: The interactions between both complexes and CT-DNA were evaluated by UV-visible spectroscopy titration and circular dichroism spectroscopy. UV-visible spectra were shown in Fig. 2. In both spectra of complexes 1 and 2, hyperchromicity was observed with the addition of CT-DNA $\left(0-8 \times 10^{-5} \mathrm{M}\right)$. The hyperchromicity argued the binding mode of these two complexes towards CT-DNA to the $6.0 \times 10^{-5} \mathrm{M}$ solution of either 1 and $\mathbf{2}$ should not be intercalation, since intercalation would bring on hypochromicity as a result of stacking effect of $\pi$ electrons ${ }^{21}$, which leads to the decrease of transition probability of $\pi$ electrons and ultimately results in the decrease of absorption. The intrinsic binding constant $\left(\mathrm{K}_{\mathrm{b}}\right)$ of $\mathbf{1}$ and $\mathbf{2}$ were calculated as $(2.02 \pm 0.02) \times 10^{3}$ and $(1.79 \pm 0.05) \times 10^{3} \mathrm{M}^{-1}$, respectively, which are much smaller than those reported for typical intercalators (e.g., EB-DNA, $\left.c a .10^{6} \mathrm{M}^{-1}\right)^{22,23}$ and comparable with some reported non-intercalateors ${ }^{24,25}$. The quite low $\mathrm{K}_{\mathrm{b}}$ values don't favour intercalation binding. Addtionally, the big cyclodextrin molecular don't favour inclusion complex 2 bind with DNA. So the higher $K_{b}$ value of $\mathbf{1}$ indicates the interaction of 1 with DNA is stronger than that of 2 .
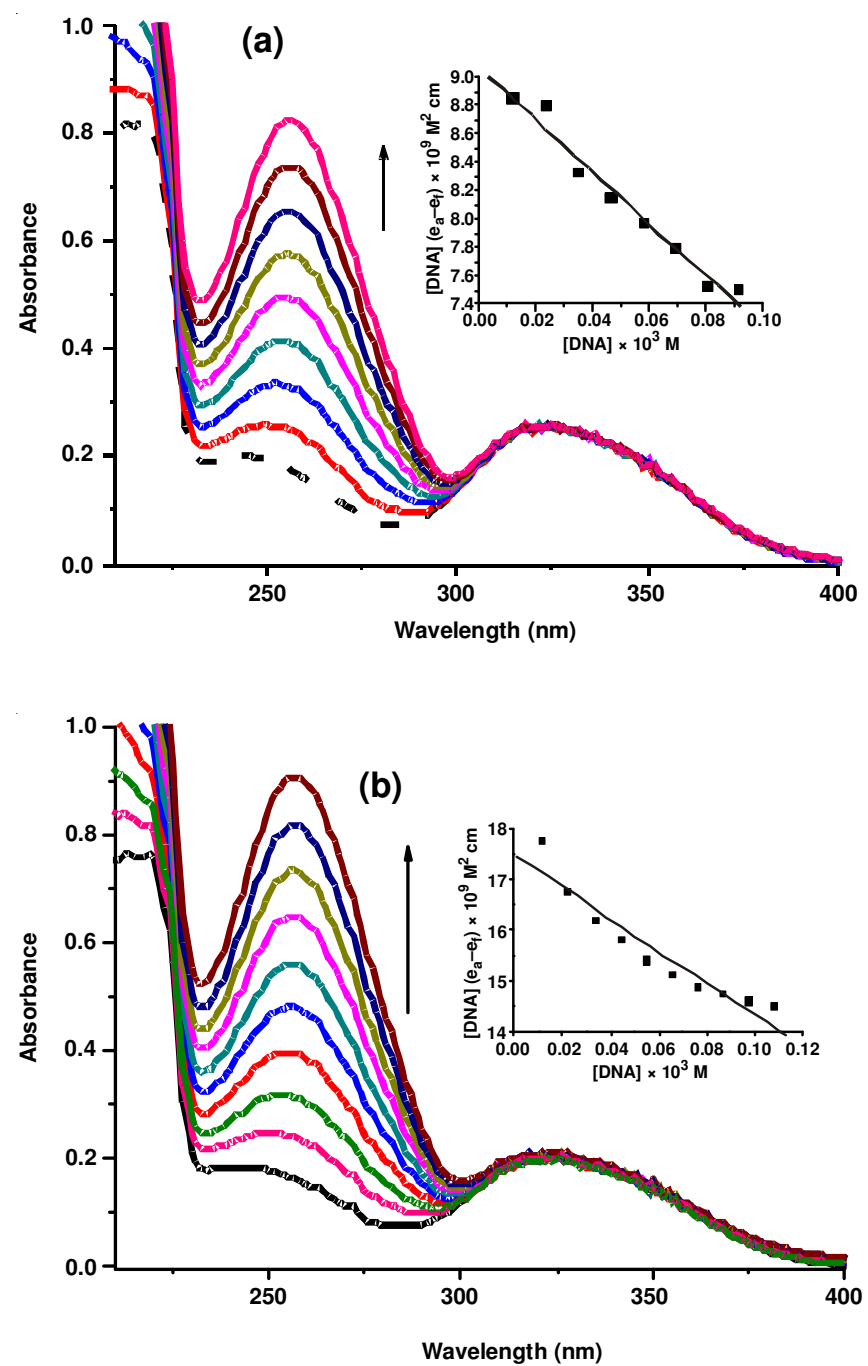

Fig. 2. Absorption spectra of $6.0 \times 10^{-5} \mathrm{M} \mathbf{1}$ (a) and 2 (b) in the absence (dot line) and the presence (solid line) of increasing amount of CTDNA $\left(0-1.0 \times 10^{-4} \mathrm{M}\right)$ in $5 \mathrm{mM}$ Tris-50 $\mathrm{mM} \mathrm{NaCl}$ buffer $(\mathrm{pH} 7.5)$ at $25 \pm 0.1^{\circ} \mathrm{C}$ 
The interaction between the two complexes and CT-DNA was further studied by circular dichroism spectroscopy (Fig. 3). The circular dichroism spectrum of CT-DNA consists of a positive band at $277 \mathrm{~nm}$ due to base stacking and a negative band at $245 \mathrm{~nm}$ because of helicity, which is characteristic of DNA in the right-handed B form ${ }^{26}$. Intercalation of small molecules with DNA enhances the intensities of both bands, while groove binding and electrostatic interactions show little or no perturbations on the base stacking and helicity bands. With increasing concentration of $\mathbf{1}$ and $\mathbf{2}$, both positive and negative bands have little change, which implied a nonintercalative mode between DNA and complexes again. The cationic core of $\mathbf{1}$ and $\mathbf{2}$ could exert a strong electrostatic attraction to the anionic phosphate backbone of DNA, thus, the electrostatic binding mode is highly possible.

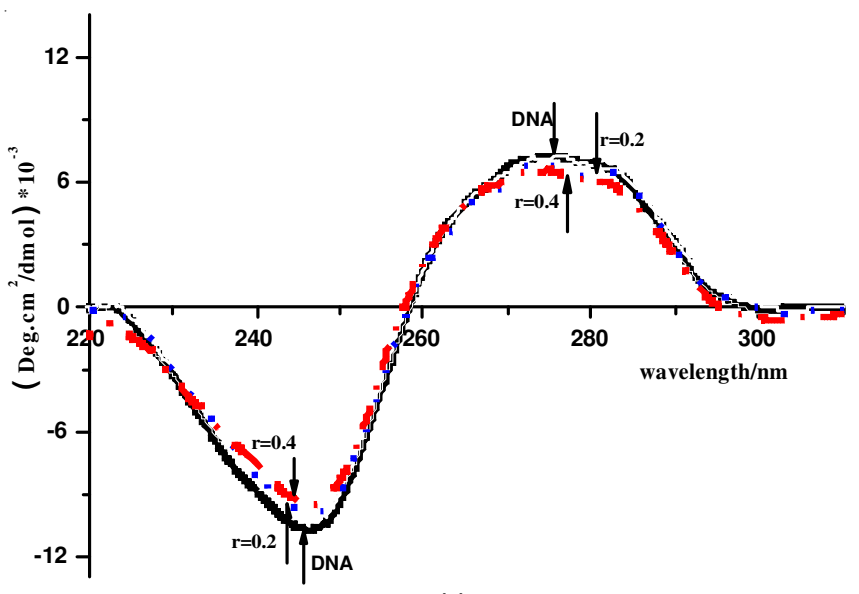

(a)

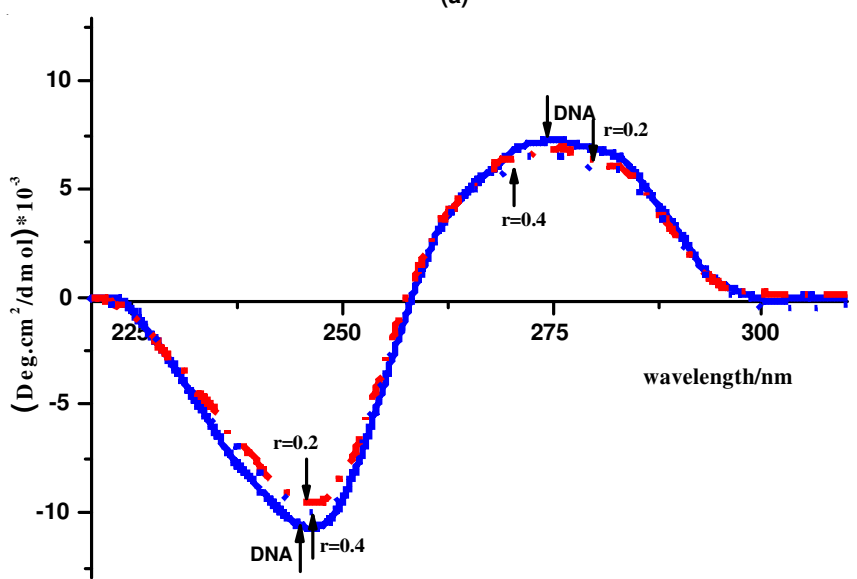

(b)

Fig. 3. Circular dichroism spectra of CT-DNA $\left(1.0 \times 10^{-4} \mathrm{M}\right)$ in the absence and the presence of $\mathbf{1}$ (a) and $\mathbf{2}$ (b) at ratio [complex]/[DNA] $=0.2$, 0.4 in $5 \mathrm{mM}$ Tris-50 mM NaCl buffer (pH 7.5)

DNA cleavage studies: The oxidative DNA cleavage activity of complex $\mathbf{1}$ and $\mathbf{2}$ were studied in the presence of ascorbic acid. Fig. 4 exhibits the concentration dependent of

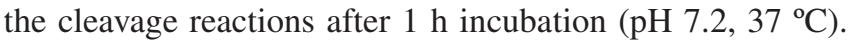
For complex 1, the amounts of form II DNA increased with the increase of complex concentration and form I DNA disappeared completely and form III started to appear when the complex concentration is up to $40 \mu \mathrm{M}$. And at $40 \mu \mathrm{M}$, form I DNA was converted to form II and form III completely. Complex $\mathbf{2}$ behaved similarly to $\mathbf{1}$ except that the greater intensity

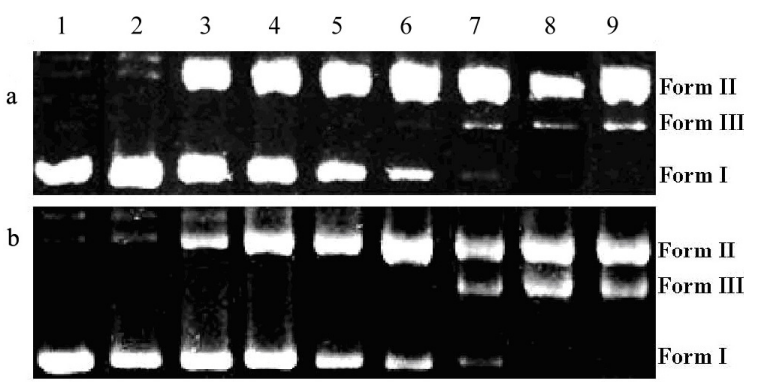

Fig. 4. Cleavage of pBR322 DNA by $\mathbf{1}$ (a) and $\mathbf{2}$ (b) in the presence of ascorbic acid. DNA (38 $\mu \mathrm{M}$ bp) was incubated with $\mathbf{1}, \mathbf{2}$ for $1 \mathrm{~h}$ in $20 \mathrm{mM}$ Tris-HClO4/0.1 $\mathrm{M} \mathrm{NaClO}_{4}$ buffer $\left(\mathrm{pH} \mathrm{7.2)}\right.$ at $37{ }^{\circ} \mathrm{C}$. Lane 1, DNA control; Lane 2, DNA + complex (100 $\mu \mathrm{M})$; Lane 3-9, DNA + complex $(5,10,20,30,40,50$ and $70 \mu \mathrm{M})+$ ascorbic acid (20-fold of complex)

of form III DNA. This suggested that $\mathbf{2}$ exhibited slightly higher nuclease activity than $\mathbf{1}$ does. The difference of nuclease activities of both complexes may be ascribed to supramolecular interaction of inclusion complex 2 .

The reactive oxygen species were also investigated, as shown in Fig. 5, the strong inhibitions of DNA cleavage to complexes $\mathbf{1}$ and $\mathbf{2}$ were observed in the presence of hydroxyl radical scavengers DMSO and tert-butyl alcohol, indicating that hydroxyl radicals are responsible for the cleavage. Singlet oxygen scavengers histidine and 2,2,6,6-tetramethyl-4piperidone monohydrate and hydrogen peroxide scavenger catalase failed to inhibit cleavage, suggesting that singlet oxygen and hydrogen peroxide are not likely to be the reactive oxygen species. A weak inhibition was observed by addition of superoxide anion radical scavenger SOD, arguing superoxide anion radical may play a role in the cleavage, but not a major active species.

a



$\mathrm{b}$

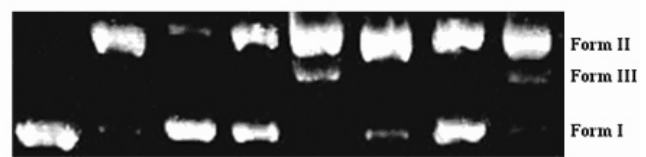

Fig. 5. Cleavage of pBR322 DNA by $50 \mu \mathrm{M} 1$ (a) and 2 (b) in the presence of different inhibitors with 20-fold excess of ascorbic acid. DNA (38 $\mu \mathrm{M} \mathrm{bp}$ ) was incubated with $\mathbf{1}$ and $\mathbf{2}$ for $1 \mathrm{~h}$ in $20 \mathrm{mM}$ Tris$\mathrm{HClO}_{4} / 0.1 \mathrm{M} \mathrm{NaClO}_{4}$ buffer ( $\mathrm{pH} 7.2$ ) at $37^{\circ} \mathrm{C}$ : Lane 1, DNA control; lane 2, no inhibitor; Lane 3, 0.5 M DMSO; lane 4, 0.5 M t-BuOH; lane 5, $1.2 \mathrm{mM}$ His; lane 6, $0.5 \mathrm{mM}$ TEMP; lane 7, $500 \mathrm{U} / \mathrm{mL}$ catalase; lane $8,500 \mathrm{U} / \mathrm{mL}$ SOD

\section{Conclusion}

The present work mainly describes the synthesis, characterization and DNA binding studies of a new supramolecular inclusion of small molecular copper complex with $\beta$ cyclodextrin. The complexes interacted with CT-DNA mainly by electrostatic attraction. Both $\mathbf{1}$ and $\mathbf{2}$ exhibited efficient nuclease activities in the presence of ascorbic acid. Especially, the inclusion complex exhibited higher nuclease activity which was attributed to the supramolecular interaction beween 
cyclodextrin molecular and DNA, and hydroxyl radicals are mainly the reactive oxygen species.

\section{ACKNOWLEDGEMENTS}

This work was supported by the National Natural Science Foundation of China (No. 21102040), Hunan Provincial Natural Science Foundation of China (Nos. 12JJ6013, 13JJ3112), Hunan Provincial Science Technology Foundation of China (No. 2012FJ3020), Foundation for University Key Teacher by Hunan Province and the construct program of the Key Discipline of Materials Physics and Chemistry in Hunan Province.

\section{REFERENCES}

1. M.L. Bender and M. Komiyama, Cyclodextrin Chemistry, SpringerVerlag, Berlin (1978).

2. J. Szejtli, Cyclodextrins and Their Inclusion Complexes, Akademiai Kiado, Budapest (1982).

3. J. Szejtli, Cyclodextrin Technology, Kluwer Academic Publishers, Dordrecht (1988)

4. K.A. Connors, Chem. Rev., 97, 1325 (1997).

5. J. Szejtli, Chem. Rev., 98, 1743 (1998).

6. G. Cravotto, A. Binello, E. Baranelli, P. Carraro and F. Trotta, Curr. Nutr. Food Sci., 2, 343 (2006).

7. A.R. Hedges and C. McBride, Cereal Foods World, 44, 700 (1999).

8. L. Zente and J. Szejtli, Trends Food Sci. Technol., 15, 137 (2004).

9. G. Astray, C. Gonzalez-Barreiro, J.C. Mejuto, R. Rial-Otero and J. SimalGa'ndara, Food Hydrocolloids, 23, 1631 (2009).
10. F. Toda and A. Ueno, Cyclodextrin Basic and Applicalion, Sangyotosho, Tokyo (1995); (c) D.R. Alston, P.R. Ashton, T.H. Lilley, J.F. Stoddart, R. Zarzycki, A.M.Z. Slawin and D.J. Williams, Carbohydr. Res., 1992, 259 (1989).

11. N.S. Krishnaveni, K. Surendra, M.A. Reddy, Y.V.D. Nageswar and K.R. Rao, J. Org. Chem., 68, 2018 (2003).

12. D.P. Shi and H.B. Ji, Chin. Chem. Lett., 20, 139 (2009).

13. B. Srinivas, V.P. Kumar, R. Sridhar, K. Surendra, Y.V.D. Nageswar and K.R. Rao, J. Mol. Catal. A, 261, 1 (2007).

14. B. Srinivas, R. Sridhar, K. Surendra, N.S. Krishnaveni, V.P. Kumar, Y.V.D. Nageswar and K.R. Rao, Synth. Commun., 36, 3455 (2006).

15. M.S. Reddy, M. Narender, Y.V.D. Nageswar and K.R. Rao, Tetrahedron Lett., 46, 6437 (2005).

16. F.J. Otero-Espinar, J.J. Torres-Labandeira, C. Alvarez-Lorenzo and J.J. Blanco-Mendez, Drug Deliv. Sci. Technol., 20, 289 (2010).

17. M.I. El-Barghouthi and Y.S. Al-Degs, Asian J. Chem., 16, 207 (2004).

18. K.P.R. Chowdary and K.S.P. Rao, Asian J. Chem., 23, 4520 (2011).

19. K. Uekama, F. Hirayama and T. Irie, Chem. Rev., 98, 2045 (1998).

20. S.-P. Tang, L. Hou, Z.-W. Mao and L.-N. Ji, Polyhedron, 28, 586 (2009).

21. E.C. Long and J.K. Barton, Acc. Chem. Res., 23, 271 (1990).

22. M. Baldini, M. Belicchi-Ferrari, F. Bisceglie, P.P. Dall'Aglio, G. Pelosi, S. Pinelli and P. Tarasconi, Inorg. Chem., 43, 7170 (2004).

23. J.B. Le Pecq and C. Paoletti, J. Mol. Biol., 27, 87 (1967).

24. J.-W. Chen, X.-Y. Wang, Y. Shao, J.-H. Zhu, Y.-G. Zhu, Y.-Z. Li, Q. Xu and Z.-J. Guo, Inorg. Chem., 46, 3306 (2007).

25. J.-H. Li, J.-T. Wang, Z.-W. Mao and L.-N. Ji, Inorg. Chem. Commun., 11, 865 (2008).

26. V. Uma, A. Castineiras and B.U. Nair, Polyhedron, 26, 3008 (2007). 